\section{Fate of The World: computer gaming for conservation?}

In Magdalene College, Cambridge, in November 2011, under the auspices of the Cambridge Conservation Initiative, a group of people gathered to debate the apparently peculiar subject of the relationship between computer games and conservation. Organized by Bruno Monteferri, a graduate of the Initiative's MPhil in Conservation Leadership and chaired by Andy Clements, Chief Executive of The British Trust for Ornithology, a panel of interested professionals debated a game called Fate of the World, released by Oxford-based computer games developer Red Redemption. On the panel were Andrew Balmford, of the Department of Zoology at the University of Cambridge, Chris Greenwood, Development Director at Fauna \& Flora International, and Jude Owers, Chief Executive of social games developer, Playmob. Speakers were Ian Roberts of Red Redemption and Tadhg Kelly, a computer games consultant.

Could the world of the young person playing a computer game be any further from the reality of conservation? It may be that the world is even madder than last time we checked but discussions sponsored by the Cambridge Conservation Initiative are soberly posing the idea that playing electronic games on computers, mobile phones, tablet computers and the like should be able to help conservation.

Essentially there are three camps in this emerging debate. Camp one says no, absolutely not, naturalists conduct conservation and these are people who live and breathe fieldwork, curious and alert from an early age to the virtues of varying form, habitat and behaviour. Naturalists, this camp says, don't divorce themselves from the world by playing computer games. They use their senses to understand the world and have to train those senses from an early age. This means being outside, not inside.

Camp two says one and half billion people, maybe more, play computer games. What's more these players aren't simply 14 year-old males with underdeveloped social skills and a liking for dark places. The average computer gamer is 42 years old and-guess what-she's female. Whether she plays Tetris (a shape manipulation game now of some heritage) or more modern games such as Farmville or Angry Birds, she is playing games a good deal of the time. She is in a new place and we conservationists can be in that same place and, with a little creativity, we can ask her to think about forests, wildlife and wild places.

Camp three admits there is an opportunity to talk to large numbers of people but prefers to get smaller numbers of people to do something as a result of knowing about conservation problems. These people point to a rather remarkable game called Fate of The World, distributed successfully through a games retailer called Steam (the world's largest distributor of computer games to PCs) in which players are asked to manage the world's resources such that its population gets healthier, happier and wealthier without causing catastrophic changes to the climate. Playing such games, or so goes the argument, will cause such an understanding of the complexities and dependencies within our habitat that the behaviour of the players will change more or less automatically.

We like education arguments (the latter), we like to tell large numbers of people about conservation (the middle option) and we are naturalists (by and large). It would be a truism to say there are virtues within each of these positions. Rather than make that point, what we can say is that in Cambridge, and elsewhere, this debate is likely to grow and we feel you ought to know about it.

Chris Greenwood Fauna \& Flora International, Cambridge, UK. E-mail chris.greenwood@fauna-flora.org

\section{New populations of an Endangered Tanzanian antelope confirmed using DNA and camera traps}

The rare, endemic and forest-dependent Abbott's duiker Cephalophus spadix of Tanzania has been in decline for several decades, leading, in 2008 , to the raising of its threat status on the IUCN Red List from Vulnerable to Endangered. Previously occurring in several highland areas in Tanzania, the local extirpation of this antelope from many of these sites over the last 100 years has slowly become apparent. The 2008 assessment estimated a maximum of 1,500 mature individuals across four disparate mountain ranges: Kilimanjaro, Usambara, Southern Highlands and the Udzungwa Mountains of southern Tanzania. The latter area was thought to hold the largest numbers and offer the greatest hope for the long-term survival of the species. Following extensive surveys across the Udzungwas, using camera traps and molecular analysis of dung to confirm results from transects and questionnaires, three new populations have now been confirmed.

From 2007 to 2010 we surveyed 24 sites in 10 forests of varying size $\left(5-522 \mathrm{~km}^{2}\right)$. At each site our primary survey method was linear transects for dung. Over $300 \mathrm{~km}$ of transect were walked and all dung and other sign of mammals recorded. However, the Udzungwa forests harbour up to five sympatric antelope species and our previous work has shown identification of antelope dung to species to be unreliable even for experienced fieldworkers and hunters (Conservation Genetics, 10, 251-255). Where present, Abbott's duikers are usually at a low density, very shy and rarely seen (in many years of fieldwork we have glimpsed the species only five times). We therefore used a combination of camera trapping and molecular analysis of 